\title{
PENGARUH PROMOSI JABATAN, KOMPENSASI DAN STRES \\ KERJA TERHADAP KINERJA KARYAWAN PT. TEMA (TRIJAYA EXCEL MADURA) MELALUI KEPUASAN KERJA
}

\author{
Wahyu Maulana \\ Universitas Madura
}

Email korespondensi: $\underline{\text { revelation10greats@gmail.com }}$

\begin{abstract}
Technological developments make economic actors to think continuously in order to survive. Individual must work hard to be the best. This condition tends to make employees depressed. The companies must act in order to produce the maximum performance and employee satisfaction in working. Based on the situation, the writer conducted a study to analyze the direct and indirect effect of the three independent variables $(X)$ (job promotion, compensation, and job stress) on the dependent variable (Y) (work performance) through variable intervening (Z) (job satisfaction). Total samples in this study were 200 persons as the informants analyzed using PLS analysis. The results show that all independent variables have a significance effect on the job satisfaction; on top of that, it is an intervening variable for all the independent variables in this study. For the work stress variable, this does not have a significance effect on the employee performance; meanwhile, for the job promotion and compensation variables, those have a significance effect on the employee performance. The dominant variable of this study is the job promotion variable.
\end{abstract}

Keywords: Job promotion, Compensation, Work Stress, Job satisfaction and Performance

\section{A. PENDAHULUAN}

Pesatnya kemajuan teknologi yang diikuti oleh perkembangan zaman yang begitu cepat membawa banyak berpengaruh ke segala bidang tanpa terkecuali termasuk di dalamnya pada dunia industri yang mengalami perkembangan yang begitu sangat pesat. Namun, faktor manusia tidak dapat dikesampingkan dikarenakan sumber daya manusia (SDM) mempunyai peranan yang penting untuk menjalankan aktivitas operasional perusahaan sehingga peranan manusia tidak bisa diabaikan begitu saja. Melalui potensi yang dimiliki oleh manusia, perusahaan dapat mencapai kesuksesan yang dituju (Suwati, 2013). Dengan demikian, SDM dapat dikatakan sebagai faktor penentu keberhasilan sebuah perusahaan. Bagi perusahaan berkembang, persoalan yang sering dihadapi adalah rendahnya kualitas SDM. Hal itu yang menjadi penghalang bagi sebuah perusahaan yang berada pada iklim persaingan yang begitu kompetitif. Persoalan ini semakin rumit dirasakan sehubungan dengan masuknya kemajuan teknologi yang memungkinkan terjadinya otomatisasi hampir di semua bidang kehidupan 
dimana hal ini akan mengubah pola hidup dan interaksi manusia (Tjandrawina, 2016). Pengelolaan SDM tidak lepas dari faktor karyawan yang diharapkan dapat berkontribusi sebaik mungkin demi mencapai tujuan perusahaan. Demi tercapainya tujuan tersebut maka karyawan harus bekerja lebih baik dan optimal agar dapat mendapatkan kepuasan kerja (Smith and Weckelly dalam As'ad, 2008). Melihat pentingnya karyawan dalam sebuah perusahaan, maka karyawan diperlukan perhatian lebih serius terhadap tugas yang dikerjakan.

Dalam meningkatkan kinerja karyawan, banyak hal yang dapat dilakukan serta berbagai macam strategi yang dapat diterapkan oleh perusahaan sehingga dapat mencapai tujuan perusahaan tersebut sesuai dengan perencanaan. Agar strategi peningkatan kinerja tersebut berhasil maka perusahaan perlu mengetahui sasaran kinerja. Dari berbagai macam penelitian terdahulu, terdapat beberapa hasil penelitian yang berbeda sehingga dari penelitian ini berangkat dari perbedaan tersebut, diantaranya penelitian yang dilakukan oleh Riyadi (2011), dimana hasil penelitiannya berupa kompensasi tidak berpengaruh positif dan tidak berpengaruh signifikan terhadap kinerja; penelitian yang dilakukan oleh Abdillah dan Wadji (2011), dimana hasil penelitiannya mengemukakan bahwa stres kerja berpengaruh negatif dan tidak berpengaruh signifikan terhadap kinerja karyawan; dan penelitian yang dilakukan oleh Jayusman dan Khotimah (2012), hasil penelitiannya berupa kesempatan promosi jabatan berpengaruh negatif dan tidak berpengaruh signifikan terhadap kinerja karyawan.

Hasil kinerja akan meningkat seiring terciptanya kepuasan kerja. Sedikitnya secara psikologis, karyawan akan bekerja dengan lebih efektif dan efisien. Dikatakan efektif bila memanfaatkan aspek dengan tepat sasaran dan dikatakan efisien bila memperhatikan aspek sehemat mungkin (Kamuli, 2012). Dengan pencapaian kepuasan kerja yang tinggi, maka karyawan akan bekerja lebih giat dalam melaksanakan pekerjaannya sehingga dengan sendirinya kinerja karyawan tersebut meningkat secara signifikan. Menurut Munandar dalam Nurandana (2012), stres kerja dapat berakibat positif yang diperlukan untuk menghasilkan prestasi yang tinggi, namun pada umumnya stres kerja lebih banyak merugikan diri karyawan maupun perusahaan. Dampak negatif dari stres kerja dapat menyebabkan ketidakpuasan kerja, meningkatnya jumlah karyawan yang keluar dan kehilangan tenaga kerja yang direkrut oleh perusahaan lain (Hemmington dan Smith dalam Nugroho, 2008). Menurut Rivai dan Sagala (2009), menegaskan bahwa apabila karyawan tidak dikelola dengan baik maka karyawan akan merasa tidak puas dengan pekerjaannya dan akhirnya memutuskan untuk mengundurkan diri (resign) dari tempat kerja. 
Dengan demikian, dapat dikatakan bahwa pada diri manusia dalam hal ini seorang karyawan terdapat suatu kebutuhan yang pada saatnya membentuk tujuan yang hendak dicapai dan dipenuhi. Demi mencapai tujuan tersebut, karyawan terdorong untuk melakukan suatu aktivitas yang dikenal dengan bekerja. Dalam mencapai kesuksesan, pimpinan perlu memperhatikan kinerja para karyawannya tersebut dalam semua aspek. Agar kepuasan kerja setiap karyawan dapat meningkat, diperlukan suatu pendorong atau faktor yang dapat membuat kepuasan karyawan tersebut sesuai dengan yang diharapkannya dan berdampak baik bagi perusahaan.

\section{B. TELAAH PUSTAKA}

\section{Promosi Jabatan}

Menurut Fathoni (2006), promosi jabatan merupakan perkembangan yang positif dari seorang pekerja atau pegawai karena tugasnya dinilai baik oleh pejabat yang berwenang. Oleh karena itu, pemberian tanggung jawab dan kewenangan yang lebih tinggi patut diberikan kepada mereka yang berprestasi. Menurut Wahyudi (2002), terdapat 4 (empat) jenis promosi jabatan diantaranya: temporary promotion; permanent promotion; small scale promotion; dan dry promotion. Menurut Hasibuan (2014), terdapat beberapa tujuan promosi jabatan diantaranya yang pertama untuk memberikan pengakuan, jabatan dan imbalan jasa yang semakin besar kepada karyawan yang berprestasi tinggi, kedua dapat menimbulkan kepuasan dan kebanggaan pribadi, status sosial yang semakin tinggi dan penghasilan yang semakin besar, ketiga untuk merangsang agar karyawan lebih bergairah bekerja, berdisiplin tinggi dan memperbesar produktivitas kerjanya, keempat untuk menjamin stabilitas karyawanan dengan direalisasinya promosi kepada karyawan dengan dasar dan pada waktu yang tepat serta penilaian yang jujur, kelima kesempatan promosi dapat menimbulkan keuntungan berantai (multiplier effect) dalam perusahaan karena timbulnya lowongan berantai, keenam memberikan kesempatan kepada karyawan untuk mengembangkan kreativitas dan inovasinya yang lebih baik demi keuntungan yang optimal perusahaan, ketujuh untuk menambah atau memperluas pengetahuan serta pengalaman kerja para karyawan dan ini merupakan daya dorong bagi karyawan lainnya, ketujuh untuk mengisi kekosongan jabatan karena pejabatnya berhenti, delapan adalah karyawan yang dipromosikan kepada jabatan yang tepat, semangat, kesenangan, dan ketenangannya dalam bekerja semakin meningkat serta produktivitasnya, kemudian kesembilan mempermudah penarikan pelamar 
sebab dengan adanya promosi merupakan daya pendorong serta perangsang bagi para pelamar untuk memasukkan lamarannya dan kesepuluh adalah promosi akan memperbaiki status karyawan dari karyawan sementara menjadi karyawan tetap setelah lulus dalam masa percobaannya.

\section{Kompensasi}

Kompensasi adalah faktor penting yang mempengaruhi bagaimana dan mengapa orangorang bekerja pada suatu organisasi dan bukan pada organisasi lainnya (Lambrie, 2010). Pengusaha harus cukup kompetitif dengan beberapa jenis kompensasi untuk memperkerjakan, memperhatikan dan memberi imbalan terhadap kinerja setiap individu di dalam organisasi. Menurut Rivai (2004), tujuan manajemen kompensasi efektif adalah memperoleh SDM berkualitas, mempertahankan karyawan yang ada, menjamin keadilan, penghargaan terhadap perilaku yang diinginkan, mengendalikan biaya, mengikuti aturan hukum, memfasilitasi pengertian, dan meningkatkan efisiensi administrasi. Menurut Simamora (2006), terdapat 2 (dua) macam kompensasi, diantaranya: kompensasi finansial dan kompensasi non finansial.

\section{Stres Kerja}

Stres kerja dilambangkan sebagai kekuatan, tekanan, kecenderungan atau upaya seseorang dalam kekuatan mental pada pekerjaannya (Salleh, dkk., 2008). Gejala stres biasanya sering marah, tidak dapat rileks, agresi, tidak kooperatif dan bisa juga melakukan pelarian yaitu dengan meminum alkohol, merokok secara berlebihan dan bahkan mungkin narkoba (Wahjono, 2010). Stres kerja merupakan suatu respon adoptif terhadap suatu situasi yang dirasakan menantang atau mengancam kesehatan seseorang (Sopiah, 2008). Menurut Robbin dan Judge (2008), secara umum, seseorang mengalami stres pada pekerjaan akan menampilkan gejala-gejala yang meliputi 3 (tiga) kategori umum, yaitu: gejala fisiologis; gejala psikologis; dan gejala perilaku.

Menurut Davis dan Newstrom dalam Mulyani (2008), stres kerja disebabkan oleh beberapa kondisi sebagai berikut: adanya tugas yang terlalu banyak; supervisor yang kurang pandai; terbatasnya waktu dalam mengerjakan pekerjaan; kurang mendapat tanggung jawab yang memadai; ambiguitas peran; perbedaan nilai dengan perusahaan; frustasi; perubahan tipe pekerjaan, khususnya jika hal tersebut tidak umum; serta konflik peran. Terdapat dua tipe umum konflik peran, yaitu konflik peran intersender dan konflik peran intrasender. 


\section{Kepuasan Kerja}

Menurut Luthans (2006), kepuasan kerja hasil dari persepsi karyawan mengenai seberapa baik pekerjaan mereka memberikan hal yang dinilai penting. Menurut Robbins (2008), job satisfaction didefinisikan sebagai suatu perasaan positif tentang pekerjaan seseorang yang merupakan hasil dari sebuah evaluasi karakteristiknya. Seseorang dengan tingkat kepuasan kerja yang tinggi memiliki perasaan positif tentang pekerjaan tersebut, sementara seseorang yang tidak puas memiliki perasaan yang negatif tentang pekerjaan tersebut. Menurut Greenberg dan Jerald (2003), terdapat beberapa cara yang dapat dilakukan untuk meningkatkan kepuasan kerja karyawan diantaranya: make jobs fun; pay people fairly; match people to jobs that fit their interests; dan avoid boring repetitive jobs.

Menurut Sunyoto (2013), kepuasan kerja adalah keadaan emosional yang menyenangkan atau tidak menyenangkan dimana para karyawan memandang pekerjaannya. Terdapat beberapa faktor yang mempengaruhi kepuasan kerja diantaranya: pekerjaan yang menantang dan kondisi kerja yang mendukung, penghargaan yang sepadan, kondisi kerja yang mendukung dan rekan kerja yang suporti, serta kesesuaian antara pekerjaan dengan kepribadian individu.

\section{Kinerja}

Kinerja merupakan hasil kerja secara kualitas dan kuantitas yang dicapai oleh seorang pegawai dalam melaksanakan tugasnya sesuai dengan tanggung jawab yang diberikan kepada seorang pegawai (Mangkunegara, 2005). Menurut Bastian (2006), kinerja adalah gambaran pencapaian pelaksanaan suatu kegiatan atau program atau kebijaksanaan dalam mewujudkan sasaran, tujuan, visi, dan misi sebuah organisasi atau perusahaan. Menurut Moeheriono (2009), kinerja adalah gambaran mengenai tingkat pencapaian pelaksanaan suatu kegiatan atau program atau kebijakan dalam mewujudkan sasaran, tujuan, misi, dan visi yang tertuang dalam strategic planing suatu organisasi atau perusahaan. Kinerja karyawan berarti produktivitas dan output karyawan sebagai hasil dari pengembangan karyawan yang pada akhirnya akan mempengaruhi efektivitas organisasi (Hameed dan Waheed, 2011).

Menurut Wibowo (2007), tujuan ukuran kinerja tersebut adalah untuk memberikan bukti apakah hasil yang diinginkan telah dicapai atau belum dan apakah muatan yang terdpat di tempat pekarja memproduksi hasil tersebut. Fokus dan isi ukuran kinerja bervariasi diantara berbagai pekerjaan. Menurut Badan Pengawas Keuangan Dan Pembangunan (BPKP) dalam Mahsun (2006), mengatakan bahwa ada beberapa manfaat untuk pengukuran kinerja 
disektor publik diantaranya yang pertama memastikan pemahaman para pelaksana akan ukuran pencapaian kinerja, kedua yaitu memastikan tercapainya rencana kinerja yang telah disepakati, ketiga yaitu memantau dan mengevaluasi pelaksanaan kinerja dan membandingkan dengan rencana kerja serta melakukan tindakan untuk memperbaiki kinerja, keempat memberikan reward \& punishment yang objektif atas prestasi pelaksana yang telah diukur sesuai dengan sistem pengukuran kinerja yang telah disepakati, keempat menjadi alat komunikasi dalam upaya memperbaiki kinerja organisasi, kelima yaitu mengindentifikasi apakah kepuasan pelanggan sudah terpenuhi, kelima adalah membantu memahami proses kegiatan instansi pemerintah, keenam memastikan bahwa pengambilan keputusan dilakukan secara objektif, ketujuh menunjukkan peringatan yang perlu dilakukan, kedelapan adalah mengungkapkan permasalahan yang terjadi.

Menurut Monil dan Tahir (2011), penilaian kinerja karyawan harus mencerminkan kualitas dan kuantitas sebagai berikut: Indikator kualitas kinerja karyawan; serta indikator kuantitas kinerja karyawan.

\section{Hubungan Promosi Jabatan, Kompensasi dan Stres Kerja Terhadap Kepuasan Kerja}

Pengaruh promosi jabatan, kompensasi dan stres kerja terhadap kepuasan kerja dapat dilihat dalam beberapa penelitian diantaranya yang dilakukan oleh Setiawan dan Sariyathi (2013). Dimana penelitian ini mengemukakan hasil yang berupa adanya pengaruh positif dan signifikan baik secara simultan maupun parsial antara promosi jabatan terhadap kepuasan kerja karyawan. Penelitian yang dilakukan oleh Siregar (2011) dimana penelitian ini menghasilkan adanya pengaruh secara langsung antara kompensasi finansial terhadap kepuasan kerja guru. Penelitian yang dilakukan oleh Potale dan Uhing (2015) menghasilkan bahwa baik secara simultan maupun parsial, stres kerja berpengaruh signifikan terhadap kepuasan kerja.

Berdasarkan latar belakang tersebut, maka terdapat beberapa hipotesis dalam penelitian ini diantaranya:

H1: Promosi jabatan berpengaruh terhadap kepuasan kerja

H2: Kompensasi berpengaruh terhadap kepuasan kerja

H3: Stres kerja berpengaruh terhadap kepuasan kerja

\section{Hubungan Promosi Jabatan, Kompensasi dan Stres Kerja Terhadap Kinerja}

Pengaruh promosi jabatan, kompensasi dan stres kerja terhadap kinerja dapat dilihat dalam beberapa penelitian diantaranya yang dilakukan oleh Yanurmawan (2012). 
menyebutkan bahwa promosi jabatan mempunyai pengaruh positif dan signifikan terhadap kinerja karyawan. Penelitian lain dilakukan oleh Hamdan dan Setiawan (2014) dengan hasil penelitian baik secara simultan maupun parsial. Kompensasi finansial dan non finansial berpengaruh signifikan terhadap kinerja karyawan. Penelitian yang dilakukan oleh Sari $d k k$ (2012) menemukan pengaruh signifikan antara stres kerja terhadap kinerja karyawan baik secara simultan maupun parsial.

Berdasarkan latar belakang tersebut, maka terdapat beberapa hipotesis dalam penelitian ini diantaranya:

H4: Promosi jabatan berpengaruh terhadap kinerja karyawan

H5: Kompensasi berpengaruh terhadap kinerja karyawan

H6: Stres kerja berpengaruh terhadap kinerja karyawan

\section{Hubungan Kepuasan Kerja Terhadap Kinerja}

Pengaruh kepuasan kerja terhadap kinerja dapat dilihat pada penelitian yang dilakukan oleh Nur (2013) hasil penelitiannya mengatakan kepuasan kerja berpengaruh positif terhadap kinerja pegawai yang artinya semakin tinggi tingkat kepuasan kerja akan memberikan dampak positif dalam meningkatkan kinerja pegawai. Berdasarkan latar belakang tersebut, maka hipotesis dalam penelitian ini adalah:

\section{H7: Kepuasan kerja berpengaruh terhadap kinerja karyawan}

\section{Kepuasan Kerja Sebagai Variabel Intervening Promosi Jabatan, Kompensasi dan Stres}

\section{Kerja Terhadap Kinerja}

Kepuasan kerja sebagai variabel intervening antara promosi jabatan, kompensasi dan stres kerja terhadap kinerja dapat dilihat dalam beberapa penelitian diantaranya yang dilakukan oleh Pratiwi (2014) mengemukakan kepuasan kerja merupakan variabel intervening diantara pengaruh promosi jabatan terhadap kinerja SDM. Penelitian lainnya yang dilakukan oleh Safrina (2017) menunjukkan bahwa kepuasan kerja memberikan efek mediasi secara penuh terhadap hubungan variabel bebas (kompensasi) terhadap variabel terikat pada penelitian ini. Penelitian lainnya dilakukan oleh Sugama (2017) yang mengatakan bahwa kepuasan kerja sebagai mediasi yang sempurna antara stres kerja dan kinerja pegawai.

Berdasarkan latar belakang tersebut, maka terdapat beberapa hipotesis dalam penelitian ini diantaranya:

H8: Kepuasan kerja merupakan variabel intervening diantara pengaruh promosi 
jabatan terhadap kinerja karyawan

H9: Kepuasan kerja merupakan variabel intervening diantara pengaruh kompensasi terhadap kinerja karyawan

H10: Kepuasan kerja merupakan variabel intervening diantara pengaruh stres kerja terhadap kinerja karyawan

\section{Kerangka Pemikiran}

Dalam penelitian ini terdapat kerangka konseptual yang menggambarkan alur pengaruh antar variabel dalam penelitian ini. Adapun kerangka konseptual adalah sebagai berikut:

Gambar 1. Kerangka Pemikiran

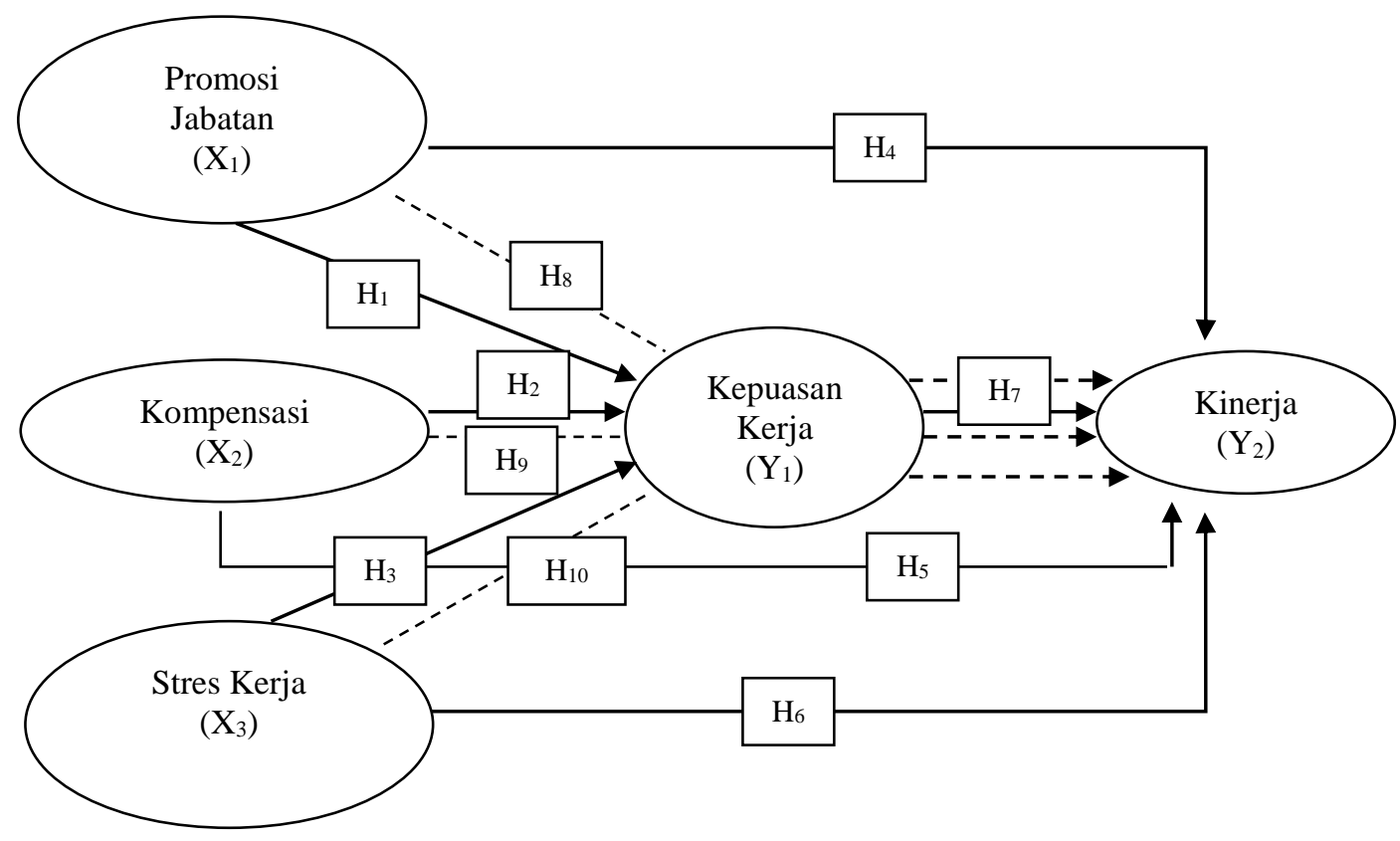

\section{METODOLOGI PENELITIAN}

Penelitian ini menggunakan 3 (tiga) jenis variabel diantaranya variabel bebas, variabel terika, serta variabel intervening. Populasi dalam penelitian ini sebanyak 400 responden dimana populasi yang dimaksud merupakan wilayah generalisasi yang terdiri atas objek atau subjek yang mempunyai kualitas dan karakteristik tertentu yang ditetapkan oleh peneliti untuk dipelajari dan kemudian ditarik kesimpulan (Trisnadewi, 2012). Menurut Arikunto (2010), sampel adalah sebagian atau wakil dari populasi yang diteliti. Dimana dalam penelitian ini, penulis mengerucutkan populasi sebanyak 400 tersebut dengan menghitung jumlah sampel tersebut menggunakan rumus slovin (Sugiyono, 2011) dengan tingkat error sebesar 5\% sehingga menghasilkan jumlah sampel sebanyak 200 responden. 
Menurut Istijanto (2005), data primer adalah data asli yang dikumpulkan oleh peneliti untuk menjawab masalah penelitiannya secara khusus sedangkan data sekunder merupakan data yang telah dikumpulkan oleh pihak lain bukan oleh peneliti sendiri untuk tujuan yang lain. Data yang dikumpulkan dalam penelitian ini bersumber dari data primer dan data sekunder. Dimana data primer ini dikumpulkan melalui kuesioner yang merupakan instrumen utama dalam penelitian ini yang berisi sejumlah pertanyaan bersifat tertutup yang disusun berdasarkan kajian teori, literatur dan pengalaman peneliti yang disebarkan serta diisi oleh responden dalam hal ini adalah karyawan melalui HRD yang ditunjukkan oleh pimpinan sebagai wakil untuk menyebarkan kuesioner tersebut. Untuk data sekunder diperoleh melalui teknik dokumentasi. Secara terperinci, metode pengumpulan data yang digunakan dalam penelitian ini berupa kuesioner dan dokumentasi. Pengukuran dalam penelitiaan ini menggunakan skala likert dengan data interval 1 (sangat tidak setuju) sampai dengan 5 (sangat setuju) (Ghozali, 2011). Skala likert digunakan untuk mengukur sikap, pendapat dan persepsi seseorang atau kelompok tentang fenomena sosial. Jawaban dari responden untuk setiap item instrumen kuesioner yang menggunakan skala likert mempunyai makna gradisi dari sangat positif sampai sangat negatif yang berupa kata-kata.

\section{Uji Validitas}

Menurut Umar (2003), validitas adalah pernyataan sampai sejauh mana data yang ditampung pada suatu kuesioner dapat mengukur apa yang ingin diukur. Suatu skala pengukuran dikatakan valid apabila skala tersebut digunakan untuk mengukur apa yang seharusnya dan inferensi yang dihasilkan mendekati kebenaran (Sarwono, 2012).

1. Convergent validity dari model pengukuran dengan refleksif indikator dinilai berdasarkan korelasi antara component score dengan construct score yang dihitung dengan PLS, dimana refleksif individual dikatakan tinggi jika berkorelasi $>0,7$ dengam konstruk yang ingin diukur. Namun demikian untuk penelitian tahap awal pengembangan skala pengukuran nilai loading 0,4 dianggap cukup, (Ghozali, 2014).

2. Discriminant validity dari model pengukuran dinilai dengan cross loading pengukuran dengan konstruk. Jika korelasi konstruk dengan item pengukuran lebih dari ukuran konstruk lainnya, maka menunjukkan konstruk laten memprediksi ukuran pada blok lebih baik daripada ukuran blok lainnya.

\section{Uji Reabilitas}

Menurut Kuncoro (2009), reliabilitas menunjukkan konsistensi dan stabilitas dari suatu 
skala pengukuran. Reliabilitas melihat sejauh mana pengukuran terhadap variabel dependen dan independen tidak rentan terhadap pengaruh yang ada dan konsisten dari variabel tersebut. Menurut Ferdinand (2006), dikatakan terpercaya apabila instrument itu secara konsisten memunculkan hasil yang sama setiap kali dilakukan pengukuran.

\section{Uji Hipotesis}

Pengujian hipotesis dilakukan dengan metode resampling bootstrap yang dikembangkan oleh Geisser dan Stone. Statistik uji yang digunakan adalah uji- t. Penerapan metode uji hipotesis, memungkinkan berlakunya data terdistribusi bebas tidak memerlukan asumsi distribusi normal, serta tidak memerlukan sampel yang besar (sampel minimum 30). Pengujian dilakukan dengan t-test, bilamana diperoleh t-value $>\mathrm{t}$-tabel (nilai t-tabel sebesar 1,96). Dari penjelasan diatas, maka dapat ditarik kesimpulan bahwa dalam analisa menggunakan PLS terdapat beberapa kriteria dalam penilaiannya.

\section{HASIL DAN PEMBAHASAN}

\section{Hasil Penelitian}

\section{Outer Model}

Gambar 2. Outer Model

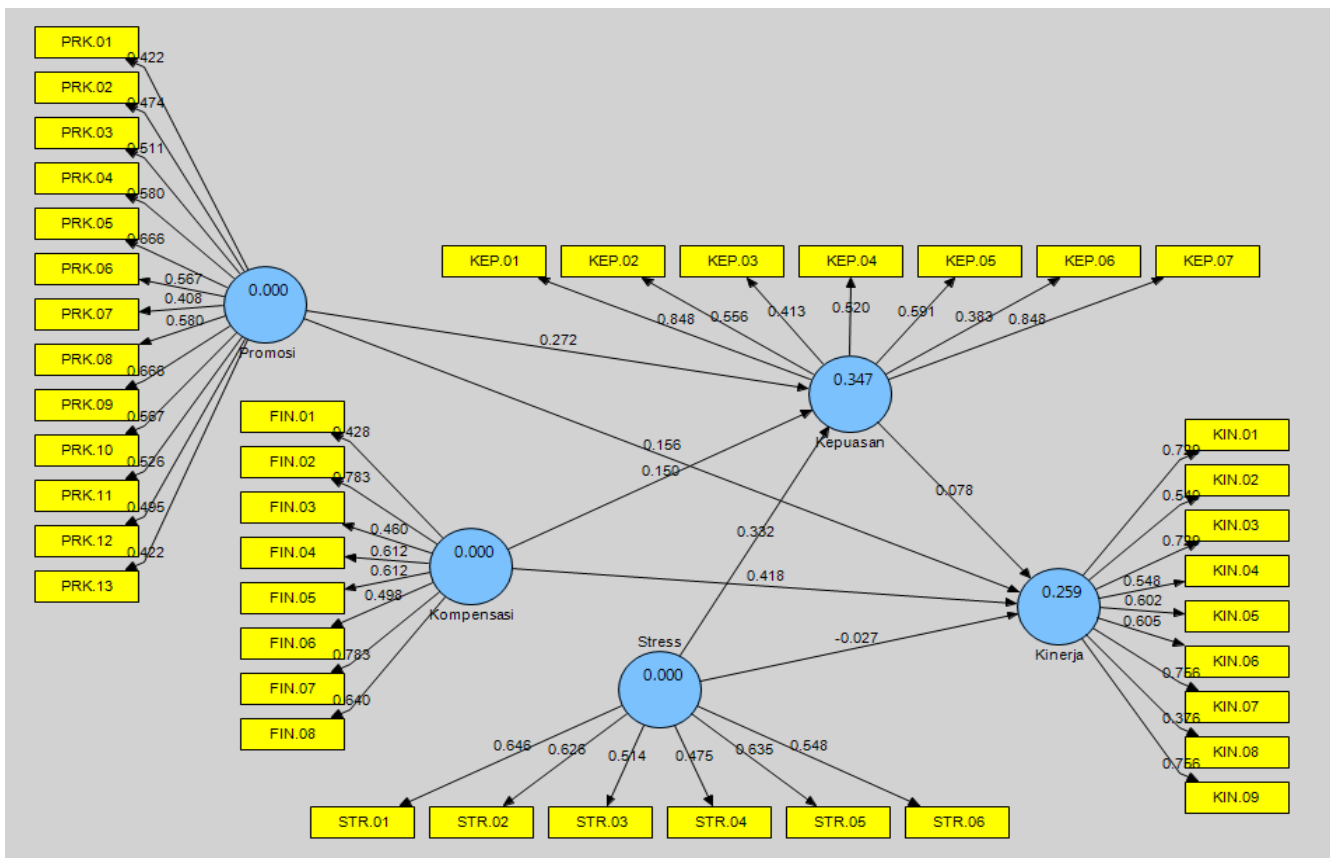

Sumber: Data diolah

Pada analisa outer model ini, dipergunakan untuk mengukur convergent validity, discriminant validity dan composite reliability. Gambar 2 merupakan model yang 
dikembangkan pada penelitian ini.

\section{Convergent Validity}

Peneliti menggunakan nilai outer loading dimana suatu indikator dikatakan memenuhinya jika memiliki nilai outer loading > 0,4. Hasilnya memperlihatkan bahwa nilai outer loading indikator variabel promosi jabatan diantaranya kecakapan, kejujuran, prestasi kerja, wewenang, kepemimpinan dan disiplin; nilai outer loading indikator variabel kompensasi diantaranya gaji, insentif, bonus, tunjangan dan asuransi; nilai outer loading indikator variabel stres kerja diantaranya kemampuan sebagai perilaku, gejala psikologi dan gejala fisiologi; nilai outer loading indikator variabel kepuasan kerja diantaranya pekerjaan itu sendiri, pimpinan, rekan kerja, promosi jabatan dan gaji; serta nilai outer loading indicator variabel kinerja karyawan diantaranya kualitas kerja, kuantitas kerja, ketepatan waktu, efektivitas dan kemandirian secara keseluruhan lebih dari 0,4. Hal ini juga memperlihatkan bahwa semua indikator yang menyusun variabel promosi jabatan, kompensasi, stres kerja, kepuasan kerja hingga kinerja karyawan yang digunakan dalam penelitian ini telah memenuhi convergent validity sehingga semua indikator ini dapat digunakan untuk analisa lebih lanjut.

\section{Discriminant Validity}

Suatu indikator dikatakan memenuhinya jika nilai cross loading indikator terhadap konstruknya adalah yang terbesar dibandingkan terhadap konstruk lainnya. Berdasarkan hasil pengujian bisa dikatakan indikator yang dipergunakan dalam penelitian berikut ini telah memiliki discriminat validity yang baik dalam menyusun variabelnya masing-masing.

\section{AVE dan Nilai Antar Konstruk}

Pengujian discriminant validity juga dilihat dari nilai akar average variance extracted (AVE) untuk setiap konstruk dan membandingkannya dengan korelasi antar konstruk. Hasil dikatakan baik apabila hasil akar AVE untuk setiap konstruknya dalam model ini lebih tinggi dari nilai korelasi antara konstruk tersebut dengan konstruk lainnya. Berdasarkan hasil pengujian, nilai korelasi antar konstruk lebih kecil jika dibandingkan dengan hasil akar AVE promosi jabatan, kompensasi dan stres kerja maka dapat disimpulkan konstruk promosi jabatan, kompensasi dan stres kerja sudah memiliki discriminant validity yang baik. Serta hasil akar AVE kepuasan kerja dan kinerja karyawan lebih besar jika dibandingkan dengan nilai korelasi antar konstruk tersebut, dengan demikian dapat disimpulkan konstruk kepuasan kerja sudah memiliki discriminant validity yang baik.

\section{Composite Reliability}


Analisa ini menguji nilai reliabilitas indikator pada suatu konstruk. Suatu konstruk atau variabel dikatakan memenuhinya jika memiliki nilai composite reliability $>0,7$. Dalam model ini, masing-masing variabel telah memenuhi composite reliability. Hasil pengujian menunjukkan nilai composite reliability untuk variabel promosi jabatan, kompensasi, stres kerja, kepuasan kerja dan kinerja karyawan secara keseluruhan semuanya lebih dari 0,7. Hal ini memperlihatkan bahwa dalam model pengukuran penelitian ini masing-masing variabel telah memenuhi composite reliability.

\section{Inner Model}

Dalam evaluasi inner model ini akan mengukur nilai R-square dan uji kasualitas. Gambar 3 adalah gambar model struktural yang dikembangkan pada penelitian ini.

\section{Gambar 3. Inner Model}

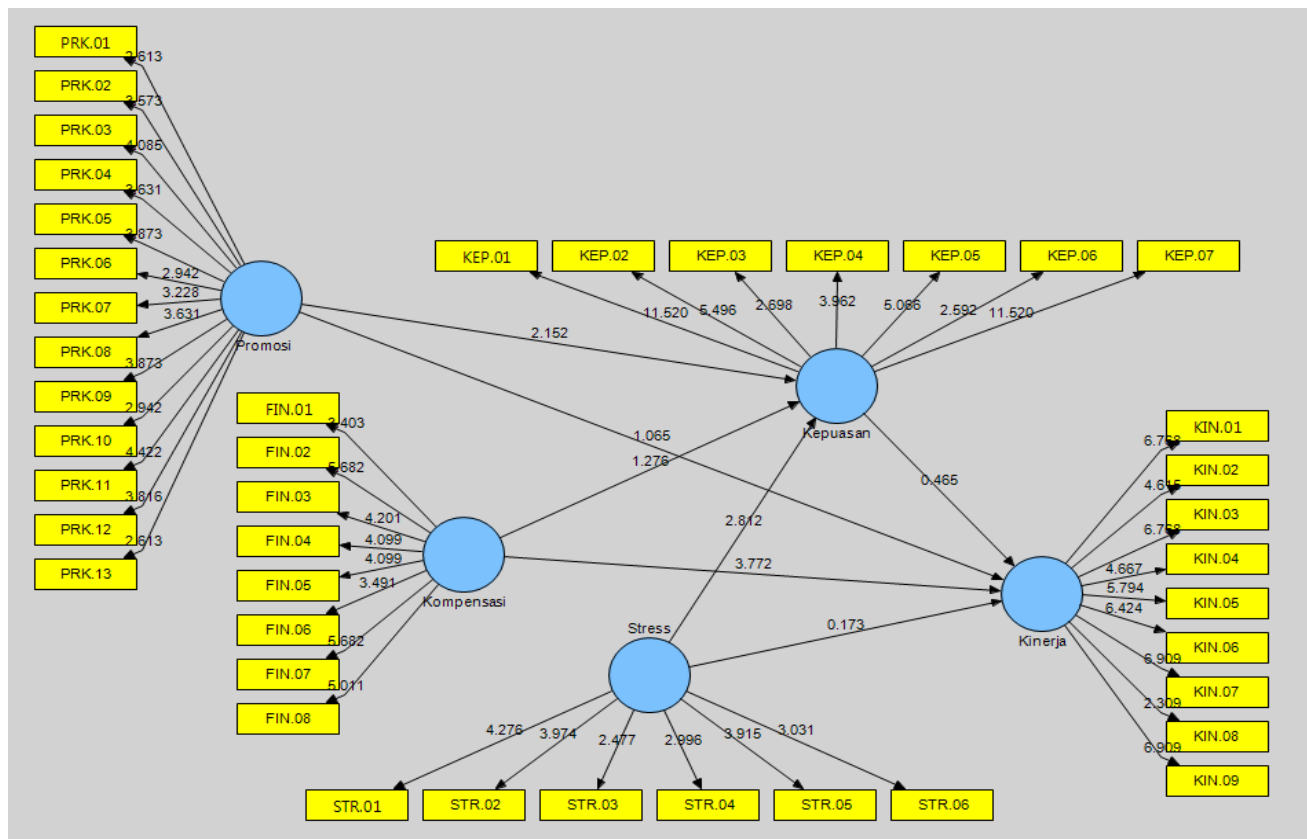

Sumber: Data diolah

\section{R-Square}

Dalam analisa Goodness of fit pada model PLS dapat diketahui dari nilai $\mathrm{Q}^{2}$. Nilai $\mathrm{Q}^{2}$ memiliki arti yang sama dengan koefisien determinasi $\mathrm{R}^{2}$ (R-Square) dalam analisis regresi. Semakin tinggi $\mathrm{R}^{2}$, maka model dapat dikatakan semakin fit dengan data. Berdasarkan pengolahan data dengan PLS, maka didapatkan model struktural penelitian ini adalah kurang baik. Hal ini disebabkan karena nilai R-Square yang diperoleh untuk kepuasan kerja sebesar $34,65 \%$ dan untuk kinerja sebesar 25,85\% dimana nilai kepuasan kerja tersebut diatas 33\% yang merupakan indikator penilaian moderat dan nilai kinerja tersebut diatas $19 \%$ yang 
merupakan indikator penilaian lemah dan dibawah 33\% yang merupakan indikator penilaian moderat.

\section{Uji Hipotesis}

Digunakan untuk menguji hipotesis penelitian dimana hipotesis ini dapat diterima jika nilai t-hitung (t-statistic) lebih besar dari t-tabel pada tingkat kesalahan $(\alpha) 5 \%$ yaitu sebesar 1,96. Tabel 2 merupakan hasil nilai koefisien path dan hasil nilai t-hitung pada inner model dalam penelitian ini.

Tabel 2. Original Sample Estimate

\begin{tabular}{|l|c|c|c|c|}
\hline & $\begin{array}{c}\text { Original } \\
\text { Sample } \\
(\mathbf{O})\end{array}$ & $\begin{array}{c}\text { Standard } \\
\text { Error } \\
(\mathbf{S T E R R})\end{array}$ & $\begin{array}{c}\text { T } \\
\text { Statistics } \\
(\mid \mathbf{O} / \mathbf{S T E R R})\end{array}$ & Keterangan \\
\hline Kepuasan -> Kinerja & 0.077883 & 0.167639 & 0.464584 & Signifikan \\
\hline Kompensasi -> Kepuasan & 0.150147 & 0.117680 & 1.275892 & Signifikan \\
\hline Kompensasi -> Kinerja & 0.418210 & 0.110886 & 3.771517 & Signifikan \\
\hline Promosi -> Kepuasan & 0.272421 & 0.126613 & 2.151607 & Signifikan \\
\hline Promosi -> Kinerja & 0.155941 & 0.146358 & 1.065478 & Signifikan \\
\hline Stress -> Kepuasan & 0.332358 & 0.118205 & 2.811720 & Signifikan \\
\hline Stress -> Kinerja & -0.027442 & 0.158275 & 0.173384 & Tidak Signifikan \\
\hline
\end{tabular}

Sumber : data diolah

\section{Indirect Effect}

Untuk mengetahui pengaruh secara tidak langsung antara variabel bebas terhadap variabel terikat melalui variabel intervening dapat dilakukan dengan mengalikan koefisien path pengaruh secara langsung variabel bebas terhadap variabel intervening dengan pengaruh secara langsung variabel intervening terhadap variabel terikat. Tabel 3 merupakan hasil perhitungan pengaruh secara tidak langsung.

Tabel 3. Indirect Effect

\begin{tabular}{|c|c|c|c|c|}
\hline \multicolumn{2}{|c|}{$\begin{array}{c}\text { Pengaruh Variabel }(\mathrm{X}) \rightarrow \\
\text { Intervening }\end{array}$} & $\begin{array}{c}\text { Kepuasan } \rightarrow \\
\text { Kinerja }\end{array}$ & $\begin{array}{l}\text { Indirect } \\
\text { Effect }\end{array}$ & Keterangan \\
\hline Promosi $\rightarrow$ Kepuasan & 0.272421 & \multirow{3}{*}{0.077883} & 0.021216965 & Intervening \\
\hline Stress $\rightarrow$ Kepuasan & 0.332358 & & 0.025885038 & Intervening \\
\hline Kompensasi $\rightarrow$ Kepuasan & 0.150147 & & 0.011693899 & Intervening \\
\hline
\end{tabular}

Sumber: data diolah

\section{Pembahasan}

Dari hasil pengujian antara variabel promosi jabatan, kompensasi dan stres kerja dengan kepuasan kerja dapat disimpulkan bahwa terdapat pengaruh positif dan signifikan terhadap kepuasan kerja karyawan. Semakin besar dibukanya peluang akan promosi jabatan, semakin meningkat kompensasi yang diberikan serta semakin baik pengelolaan stres kerja yang ada pada perusahaan maka akan meningkatkan kepuasan kerja karyawan PT. TEMA. 
Hasil penelitian ini mendukung penelitian yang telah dilakukan oleh Setiawan dan Sariyathi (2013). Dimana penelitian ini mengemukakan hasil yang berupa adanya pengaruh positif dan signifikan baik secara simultan maupun parsial antara promosi jabatan terhadap kepuasan kerja karyawan; serta penelitian yang dilakukan oleh Siregar (2011) dimana penelitian ini menghasilkan adanya pengaruh secara langsung antara kompensasi finansial terhadap kepuasan kerja guru; dan penelitian yang dilakukan oleh Potale dan Uhing (2015) menghasilkan bahwa baik secara simultan maupun parsial, stres kerja berpengaruh signifikan terhadap kepuasan kerja.

Dari hasil pengujian antara variabel promosi jabatan dan kompensasi dengan kinerja karyawan dapat disimpulkan bahwa terdapat pengaruh positif dan signifikan terhadap kinerja karyawan. Semakin besar dibukanya peluang akan promosi jabatan dan semakin meningkat kompensasi yang diberikan maka meningkatkan pula kinerja karyawan PT. TEMA. Hasil penelitian ini mendukung penelitian yang telah dilakukan oleh Yanurmawan (2012) menyebutkan bahwa promosi jabatan mempunyai pengaruh positif dan signifikan terhadap kinerja karyawan. Penelitian yang dilakukan oleh Hamdan dan Setiawan (2014) dengan judul "Pengaruh kompensasi finansial dan non finansial terhadap kinerja karyawan PT. Samudera Buana Persada" dengan hasil penelitian baik secara simultan maupun parsial. Kompensasi finansial dan non finansial berpengaruh signifikan terhadap kinerja karyawan. Sedangkan untuk hasil pengujian variabel stres kerja dengan kinerja karyawan menghasilkan pengaruh negatif dan tidak signifikan. Artinya meskipun pengelolaan stres kerja sudah baik, tetapi kinerja karyawan tidak membaik dikarenakan banyaknya tekanan dalam menjalankan tugas untuk mencapai target yang telah ditentukan oleh perusahaan. Hasil penelitian ini mendukung penelitian yang telah dilakukan oleh Mahardiani dan Pradhanawati (2013) dimana hasil penelitiannya mengatakan hasil perhitungan menunjukkan bahwa variabel stres kerja tidak berpengaruh signifikan terhadap kinerja.

Dari hasil pengujian antara variabel kepuasan kerja dengan kinerja karyawan dapat disimpulkan bahwa terdapat pengaruh positif dan signifikan terhadap kinerja karyawan. Semakin besar kepuasan kerja yang dirasakan oleh karyawan maka makin meningkatkan pula kinerja karyawan PT. TEMA. Hasil penelitian ini mendukung penelitian yang telah dilakukan oleh Nur (2013) dimana hasil penelitiannya mengatakan kepuasan kerja berpengaruh positif terhadap kinerja pegawai yang artinya semakin tinggi tingkat kepuasan kerja akan memberikan dampak positif dalam meningkatkan kinerja pegawai. 
Dari hasil pengujian kepuasan kerja merupakan variabel intervening promosi jabatan, kompensasi dan stres kerja terhadap kinerja karyawan dapat disimpulkan bahwa kepuasan kerja sebagai variabel intervening promosi jabatan, kompensasi dan stres kerja terhadap kinerja karyawan. Hasil penelitian ini mendukung penelitian yang telah dilakukan oleh Pratiwi (2014) dimana hasil penelitiannya mengemukakan kepuasan kerja merupakan variabel intervening diantara pengaruh promosi jabatan terhadap kinerja SDM. Penelitian lainnya yang dilakukan oleh Safrina (2017) menunjukkan bahwa kepuasan kerja memberikan efek mediasi secara penuh terhadap hubungan variabel bebas (kompensasi) terhadap variabel terikat pada penelitian ini. Penelitian lainnya dilakukan oleh Sugama (2017) hasil penelitian ini mengatakan bahwa kepuasan kerja sebagai mediasi yang sempurna antara stres kerja dan kinerja pegawai.

\section{E. KESIMPULAN}

Dari beberapa hasil analisa dan pembahasan diatas, dapat ditarik sebuah kesimpulan bahwa adanya kepuasan kerja dalam perusahaan ini dipengaruhi oleh adanya promosi jabatan yang merata dan terbuka, kompensasi yang memadai serta pengelolaan stres kerja yang baik. Untuk meningkatkan kinerja para karyawan lebih optimal, faktor perolehan kompensasi yang sesuai dengan pekerjaan dan guna meraih kesempatan untuk promosi jabatan ke level yang lebih meningkat memiliki pengaruh yang signifikan dalam perusahaan ini sedangkan untuk stres kerja dalam mencapai kinerja yang baik belum memiliki pengaruh yang tidak signifikan.

Dengan hasil penelitian tersebut, muncul saran yang membangun yakni perlu terus menjaga kestabilan dalam pengelolaan stres kerja yang baik bagi karyawan agar terjaga pula kepuasan kerja serta kinerja karyawan. Diharapkan kedepan untuk peneliti selanjutnya agar dapat menggunakan lebih banyak lagi variabel untuk mengukur kepuasan kerja dan kinerja karyawan ataupun merubah variabel yang pernah digunakan dengan variabel lainnya.

Keterbatasan dalam penelitian ini berupa penggunaan variabel bebas untuk mengukur kepuasan kerja dan kinerja karyawan yang masih terbatas sehingga masih miskin dalam penggunaan variabel penelitian ini. Namun, penggunaan variabel ini sudah dirasa dapat mewakili dalam pengukuran kepuasan kerja dan kinerja karyawan.

\section{DAFTAR PUSTAKA}

Abdillah, Arief Chaidir dan Wajdi, Farid. (2011). Pengaruh kepemimpinan, stres kerja, disiplin kerja dan kompensasi dengan kinerja pegawai. Jurnal Ekonomi Manajemen Sumber Daya DAYA 
SAING Vol. 12 No. 1 Juni 2011 ISSN : 1411-3422

Arikunto, Suharsimi. (2010). Prosedur Penelitian Suatu Pendekatan Praktek Edisi Revisi. Renika Cipta: Yogyakarta.

As'ad, Moh. (2008). Psikologi Industri. Liberty : Yogyakarta.

Bastian, Indra. (2006). Akuntansi Sektor Publik Suatu Pengantar. Erlangga : Jakarta.

Fathoni, Abdurrahmat. (2006). Manajemen Sumber Daya Manusia. Rineke Citra : Jakarta

Ferdinand, Augusty. (2006). Metode Penelitian Manajemen Pedoman Penelitian Untuk Penulisan Skripsi, Tesis dan Disertasi Ilmu Manajemen Edisi Kedua. Badan Penerbit Universitas Diponegoro : Semarang.

Ghozali, Imam. (2011). Aplikasi Analisis Multivariate Dengan Program IBM SPSS 19. Universitas Diponegoro : Semarang.

Ghozali, Imam. (2014). Structural Equation Modeling Metode Alternatif Dengan Partial Least Square Edisi 4 Dilengkapi Software SmartPLS 3.0 Xlstat 2014 dan WarpPLS 4.0. Universitas Diponegoro : Semarang.

Greenberg dan Jerald, Robert Baron. (2003). Behavior In Organizations (Understanding and Managing The Human Side of Work). Eight Edition. Prentice Hall.

Hamdan, Ekshu dan Setiawan, Roy. (2014). Pengaruh kompensasi finansial dan non financial Terhadap kinerja karyawan PT. Samudera buana persada. Jurnal Agora vol. 2 no. 1 Th 2014

Hameed, A and Waheed. (2011). Employee Development and Its Affect on Employee Performance : A Conceptual Framework. International Journal of Business and Social Science. Vol 2 No 13 pp : 224-229

Hasibuan, Malayu. (2014). Manajemen Sumber Daya Manusia Edisi Revisi. PT Bumi Aksara : Jakarta

Istijanto. (2005). Aplikasi Praktis Riset Pemasaran. Gramedia Pustaka Utama : Jakarta.

Jayusman, Hendra dan Khotimah, Siti. (2012). Pengaruh kepemimpinan, komunikasi, motivasi, pengembangan karir, dan Promosi jabatan terhadap kinerja pegawai kantor sekretariat daerah Kabupaten kota waringin barat. Jurnal SPREAD Vol 2 No 2 oktober 2012

Kamuli, S. (2012). Pengaruh iklim organisasi terhadap produktivitas kerja pegawai di Sekretariat Daerah Kota Gorontalo. Jurnal Inovasi Vol. 9 No. 1 Tahun 2012 ISSN : 1693-9034

Kuncoro, Mudrajad. (2009). Metode Riset untuk Bisnis dan Ekonomi. Erlangga : Jakarta.

Lambrie, Irianto. (2010). Manajemen Sumber Daya Manusia. Laks Bang Preesindo : Yogyakarta

Luthans, Fred. (2006). Perilaku Organisasi. Andi : Yogyakarta.

Mahardiani, Yoanisa dan Pradhanawati, Ari. (2013). Pengaruh stres kerja dan lingkungan kerja fisik terhadap Kinerja karyawan outsourcing pada PT. Bank Jateng Cabang Koordinator Dan Cabang Pembantu Wilayah Kota Semarang. Jurnal Administrasi Bisnis Vol 2 No 1 Maret 2013 ISSN : 2252-3294 
Mahsun, Mohammad. (2006). Pengukuran Kinerja Sektor Publik Edisi Pertama. BPFE : Yogyakarta

Mangkunegara, Anwar Prabu. (2005). Manajemen Sumber Daya Manusia Perusahaan. PT. Remaja Rosdakarya : Bandung

Moeheriono. (2009). Pengukuran Kinerja Berbasis Kompetensi. Ghalia Indo : Bogor

Monil, Muzalifah dan Tahir, Izah Mohd. (2011). Determinants of Job Performance in Frontline Employees in Malaysia Using Structural Equation Model : A Proposed Conceptual Framework. International Journal of Business and Behavioral Sciences. 1/1 pp : 32-42

Mulyani, S. (2008). Pengaruh Stres Kerja terhadap Afektivitas Negatif, Pemberdayaan Psikologis, Kepuasan Kerja dan Kinerja. Disertasi. Universitas Brawijaya : Malang

Nugroho, Adityo. (2008). Analisis Pengaruh Job Stres dan Job Satisfaction Terhadap Turnover Intention (Studi pada PT. Astra Graphia. Tbk). Tesis. Magister Manajemen Program Pasca Sarjana Universitas Diponegoro. Semarang

Nur, Saina. (2013). Konflik, stress kerja dan kepuasan kerja pengaruhnya terhadap kinerja pegawai pada Universitas Khairun Ternate. Jurnal EMBA 1/3 2013 pp : 739-749 ISSN : 2303-1172

Nurandana, Agung. (2012). Pengaruh stres kerja terhadap kinerja karyawan PT. PLN (persero) cabang Makassar. Skripsi tidak diterbitkan. Jurusan Manajemen Fakultas Ekonomi Universitas Hasanuddin. Makassar

Potale, Rocky dan Uhing, Yantje. (2015). Pengaruh kompensasi dan stres kerja terhadap kepuasan kerja karyawan Pada PT. Bank Sulut Cabang Utama Manado. Jurnal EMBA 3/1 2015 Hal. 6373 ISSN : 2303-1174

Pratiwi, Dwi Mina. (2014). Pengaruh iklim organisasi dan promosi jabatan terhadap kinerja SDM dengan kepuasan kerja sebagai variabel intervening pada Bank BRI cabang Demak. Skripsi yang tidak dipublikasikan. Fakultas Ekonomo Universitas Islam Sultan Agung Semarang

Rivai, Veitzhal. (2004). Manajemen Sumber Daya Manusia Untuk Perusahaan. Murai Kencana : Jakarta

Rivai, Veithzal dan Sagal, Jauvani. (2009). Manajemen Sumber Daya Manusia untuk Perusahaan dari Teori ke Praktik. Edisi Kedua. Rajawali Press : Jakarta

Riyadi, Slamet. (2011). Pengaruh kompensasi finansial, gaya kepemimpinan, dan motivasi kerja Terhadap kinerja karyawan pada perusahaan manufaktur di jawa timur. Jurnal manajemen dan kewirausahaan vol. 13 no. 1 maret 2011 pp : 40-45. p-ISSN : 1411-1438 e-ISSN : 23388234

Robbin, Stephen. (2008). Perilaku Organisasi. PT. Indeks : Jakarta.

Robbins, SP and Judge, TA. (2008). Perilaku Organisasi Edisi 12 buku 1. Salemba Empat : Jakarta

Safrina, Emi. (2017). Pengaruh disiplin, kompensasi dan komunikasi terhadap kinerja karyawan dengan kepuasan kerja sebagai variabel intervening pada Stasiun Pengisian Bahan Bakar Umum (SPBU) di Kabupaten Bireuen. Jurnal ekonomi dan bisnis Vol 18 No 2 Agustus 2017. pISSN : 1693-8852 e-ISSN : 2549-5003

Salleh, AL, Bakar, RA, Keong, WK. (2008). How Detrimental is Job Stres? : A Case Study Of Executives in the Malaysian Furniture Industry. International Review of Business Research 
Papers, 4(5)

Sari, Rahmila., dkk. (2012). Pengaruh kepemimpinan, motivasi, dan stres kerja terhadap kinerja Karyawan pada bank syariah mandiri kantor cabang Makassar. Jurnal Analisis Vol. 1 No. 1 Juni 2012 pp : 87-93 ISSN : 2303-1001

Sarwono, Jonathan. (2012). Path Analysis Dengan SPSS. PT. Elex Media Komputindo : Jakarta.

Setiawan, I Wayan Oky dan Sriyathi, Ni Ketut. (2013). Pengaruh kompensasi finansial, promosi Jabatan dan lingkungan kerja fisik terhadap Kepuasan kerja karyawan pada parigata resort And spa sanur - bali. E-jurnal manajemen Universitas Udayana 2/7 2013 ISSN : 2302-8912

Simamora, Henry. (2006). Manajemen Sumber Daya Manusia Edisi Kedua. STIE YKPN : Yogyakarta

Siregar, Edi. (2011). Pengaruh motivasi kerja, kinerja individual dan system kompensasi financial terhadap kepuasan kerja. Jurnal PENABUR. ISSN : 1412-2588 pp : 81-93

Sopiah. (2008). Perilaku Organisasional. Penerbit Andi : Yogyakarta

Sugama, I Dewa Gede Yoga. (2017). Pengaruh stres kerja dan motivasi terhadap kinerja pegawai melalui kepuasan kerja sebagai variabel intervening pada Unit Layanan Pengadaan (ULP) Provinsi Bali. JAGADHITA : Jurnal Ekonomi dan Bisnis Vol 4 No 1 Maret 2017 pp : 11-26 DOI : 10.22225/JJ.4.1.205.11-26

Sugiono. (2011). Metode Penelitian Kuantitatif Dan Kualitatif Dan R\&D. Alfabeta : Bandung.

Sunyoto, Danang, (2013). Manajemen Sumber Daya Manusia. APS (Center For Academic Publishing Service): Yogyakarta.

Suwati, Y. (2013). Pengaruh kompensasi dan motivasi kerja terhadap kinerja karyawan. Jurnal ilmu administrasi dan bisnis Vol. 1 No. 1 tahun 2013

Tjandrawina, RR. (2016). Industri 4.0 : revolusi industry abad ini dan pengaruhnya pada bidang kesehatan dan bioteknologi. Jurnal Medicinus Vol. 29 No. 1

Trisnadewi, Dewa Ayu Ari. (2012). Pengaruh Kompensasi Finansial Dan Kepemimpinan Terhadap Kepuasan Kerja Karyawan Pada Hotel Barong Bali Di Legian, Kuta Badung. Proposal penelitian yang tidak dipublikasikan. Fakultas Ekonomi Universitas Warmadewa Denpasar.

Umar, Husein. (2003). Metode Riset Bisnis. Gramedia Pustaka Utama : Jakarta.

Wahjono, Sentot Imam. (2010). Perilaku Organisasi. Graha Ilmu : Yogyakarta

Wahyudi, Bambang. (2002), Manajemen Sumber Daya Manusia. Sulita : Bandung.

Wibowo. (2007). Manajemen Kinerja. PT. Raja Grafindo Persada : Jakarta

Yanurmawan, Dion. (2012). Pengaruh promosi jabatan terhadap kinerja karyawan dikaji Menurut teori Alderfer (studi di PT. BPR Gunung Ringgit Malang). Jurnal akuntansi dan ekonomi bisnis Vol. 1 No. 1 april 2012 